\title{
The Truth of Dharma and the Dharma of Truth: Reflections on Hinduism as a Dharmic Faith
}

\author{
Julius Lipner
}

Published online: 7 December 2019

(C) The Author(s) 2019

\begin{abstract}
This article discusses what it might mean to characterize traditional Hinduism as a dharmic faith in relation to the concepts of truth (satyam) and its opposite (anrtam), without however expatiating on supposed contrasts between Hinduism and the "Abrahamic" faiths. The argument is conducted by recognizing two senses to anrtam, namely, "non-truth" and "falsehood," in contrast to satyam; and the method used is inductive in that a historically well-known episode of the Mahäbhärata - the story of Kauśika and the bandits - and its authoritative interpretation by the deity Kṛ̣na in terms of satyam and anrtam (in the Karnaparvan, Book 8, of the text) are analyzed heuristically to indicate how dharma is viewed in the tradition qua ethical concept. The conclusion is drawn that Hindu dharma is understood as that whose objective is ultimately to bring about the welfare of the world (lokasangraha). In relation to truth (and its opposite), materially, dharma is invariably contextual in connotation (in contrast to what might be a Kantian or absolutist reading of moral imperatives), whereas formally, at the hands of one commentator or other, not least in modern times, dharma is that which defines what it means to be Hindu. The material and formal connotations of dharma thus analyzed and taken together set Hinduism apart qua dharmic faith.
\end{abstract}

Keywords Hindu dharma $\cdot$ satyam/truth $\cdot$ anrtam/non-truth/falsehood · lokasangraha · ethical contextualism versus absolutism · Hinduism and modernity

Julius Lipner

jj11000@cam.ac.uk

Emeritus Professor of Hinduism and the Comparative Study of Religion, Faculty of Divinity, University of Cambridge, Cambridge CB3 9BS, UK 
The official motto for the Indian state, adopted in 1950, is satyam eva jayate. ${ }^{1}$ This declaration may be translated as "Truth alone conquers," or perhaps "Truth alone prevails." Apparently, the state's founding fathers wished to put the pursuit of truth at the heart of the new nation. Many important questions tied up with religious faith, and political and social representation, underlie the choice of this motto in Sanskrit, but these are beyond the scope of this article. Here we focus on the declaration of the aspiration itself, which we can suppose most factions concerned would not have objected to qua aspiration. It appears in the Muṇdaka Upanișad, generally dated to a few centuries before the Common Era. The declaration's meaning becomes clearer when we take it in context. The Mundaka (3.1.1) is speaking of two closely bound companions, one immersed in the experiences of life, the other a witness. When the experiencer eventually becomes a sage (yati) by disengaging one's self from the multiple attachments of everyday life through the pursuit of truth, austerity, right knowledge, and purity (3.1.5), then it is the companion, the divine witnessing self, that becomes the constant source of attention and delight. It is at this point that our text comes into play, which I translate as follows:

Truth (satyam) alone conquers, not untruth (anrtam). By truth (satyena) the path leading to the Divine is spread out, by which the seers, their desires fulfilled, approach That which is the highest abode of truth-and-being (satyasya) (3.1.6). ${ }^{2}$

There are a couple of features of the Sanskrit here that are noteworthy for our purposes. First, in general, satyam can be translated as both "truth" and "being" or "reality,", while anrtam - the negative of rtam — can be translated as "non-truth," and also as "untruth" or "falsehood," or even as "non-real" or "unreal" (the negative being susceptible of both the stronger and weaker senses of this term). This derives from a longstanding grammatical rule in Sanskrit whereby the (negative)

\footnotetext{
1 This paper was first presented at the Backwaters Collective on Metaphysics and Politics conference at Cochin, India in July 2018. I am grateful for the discussion that followed and especially for comments by Professors Ganesh N. Devy, D. Venkat Rao, and Ajay Skaria. "Hinduism" no doubt is a problematic term, but I have argued in the past for retaining it as a marker of identity for culture, faith, and follower. If there are, conventionally, "Christians," "Buddhists," and "Muslims," then there are "Hindus." Similarly, if there are "Christian," "Buddhist," and "Muslim" texts, then there are also "Hindu" texts. With reference to texts and other sources cited, I hope I am using this descriptor in a pragmatically acceptable and uncontroversial way.

2 satyam eva jayate nānṛtam, satyena panthā vitato devayānah I yenākramanty rșayo hy āptakāmā, yatra tat satyasya paramam nidhānam ॥ (Muṇ ḍaka Upaniṣad 3.1.6).

3 This is why I have translated the final satyam of 3.1 .6 as "truth-and-being."
} 
prefix " $a$-/an-" becomes susceptible of a range of meanings. ${ }^{4}$ The ambiguity-and in the case of anrtam here, also ambivalence - of these meanings are significant for our purposes, with context being our guide for what the sense might be in one occurrence or other of the term.

Second, note the juxtaposition of satyam and anrtam in our text. This particular verbal face-off is not uncommon in Sanskrit literature, as we shall see. We can now expand a little on these points to clarify the course of our argument.

On satyam as connoting both "truth" and "reality/being," let us consider briefly a portion of the great Advaitin, or non-dualist, Śankara's (eighth-century) interpretation of a statement from the Taittirīya Upanișad (perhaps a couple of centuries earlier than the Mundaka). The Taittiriya starts as follows with reference to the Supreme Being, Brahman:

Om. The knower of Brahman obtains the Supreme. On that, this has been said: "Brahman is Being/Truth (satyam), Knowledge (jñānam), Eternal (anantam)..." $(2.1 .1)^{5}$

We need not concern ourselves with all the exegetical details. ${ }^{6}$ However when explaining satyam here, Śankara says:

With respect to satyam we say: that whose form (or nature, rūpa) is known for certain as undeviating, is satyam, whereas that whose form (or nature) is ascertained as deviating, is said to be anrtam. Hence change (vikāra) is anrtam...So, "Brahman is satyam" means that Brahman resiles from change [that is, Brahman is unchanging] (1964: 283; my translation). ${ }^{7}$

Note both the verbal and conceptual confrontation here between satyam and anrtam in Śankara's explanation. But how to translate these terms? Because of Śankara's

\footnotetext{
${ }^{4}$ Matilal notes: "The symbol 'nañ' stands, in general, for all the negative particles in Sanskrit. Thus the free particles ' $n a$,' 'no,' etc., and the bound particles ' $a$-' and 'an-' in compounds [for example, anrta] are included under this general name.... The following couplet is quoted by the grammarians to enumerate the

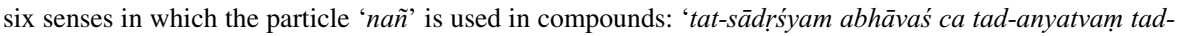
alpatā, aprāśastyam virodhaś ca nañ-arthāh șat prakīrtitāh' [which I translate as: "Similarity to its (counterpositive) and absence of it, difference from it and scarcity of it, criticism (of it) and opposition (to it): these are the six established senses of nañ (the negative prefix)]." He continues with examples of each sense: “(i) similarity, as in 'a-brāhmaṇah (like a brahmin)'; (ii) (relational) absence, as in 'a-pāpam (absence of sin)'; (iii) difference or mutual absence, as in 'an-aśvah (other than a horse)'; (iv) smallness or scarcity, as in 'an-udarā kanyā (a girl with a thin waist)'; (v) impropriety, as in 'a-paśavo'nye (other animals are ill-suited [for the sacrifice in question]'; (vi) contrariety, as in 'a-dharmah (contrary to merit, demerit)'" (1968: 148). These examples of the negative prefix in compounds are well known and are given, for example, by Kauṇuabhațta ( $c a$. first half of the seventeenth century) in his Vaiyākaranabhüșaṇasāra in the Nañarthanirṇaya chapter (see Kauṇụabhațta 1957: 360. I am grateful to Professor Varun Khanna for locating this reference for me). For our purposes, we focus on the senses of anrtam as "absence of truth" and as "contrary to truth"; the former, as we shall go on to explain, does not imply falsehood, while the latter does.

5 om | brahmavidāpnoti param | tadeșābhyuktā | satyam jñānamanantam brahma... I (Taittirīya Upanișad 2.1.1).

6 On this, see my "Śañkara on Satyam Jñānam Anantam Brahma" (Lipner 1997).

7 satyamiti yadrūpeṇa yanniścitam tadrūpam na vyabhicarati, tat satyam I yadrūpena yanniścitam tadrūpam vyabhicarad anṛtam ity ucyate I ato vikāro'nrtam ... I atah satyam brahmeti brahma vikārān nivartayati $\mid$
} 
preoccupation with "change" and "non-change," we must plump here, I think, for some such translation as "Reality" or "the Real" for satyam. So the meaning is, because Brahman is unchanging in nature, It is the Real, or Reality itself. In that case, anrtam is what is unreal, that is, not truly real or existent; in other words, because it changes it is not real per se in the way Brahman is Real. Śankara goes on to say that everything other than Brahman is unreal, or rather, real only in so far as it depends on Brahman for its causal being.

But there is a subtlety to Śankara's use of words. Vyabhicar-, namely, the verbal root Śankara uses in the first instance for "change," 8 can also refer to a process of moral deviation from some norm, like a transgression or $\sin ,{ }^{9}$ or even to inflicting harm or injury. This lets in the connotation of "Truth" for satyam, and "untruth" or "falsehood" for anrtam, because we are speaking here of a moral deviation. The alternative translation for Śankara's explanation would then have the sense of:

With respect to satyam we say: Brahman is Truth itself, because It has a form or nature that is known for certain not to deviate [from what It is qua truth], while that whose form or nature is ascertained as liable to fall away [from the truth of its being], is said to be anrtam. Hence change in the sense of liability to fall away in a moral sense is anrtam....So, "Brahman is satyam" means that Brahman is Truth itself.

Śankara's careful interpretation of this Upanișad is one of the earliest commentaries we have, so- his Advaitic leanings apart—perhaps we can assume that, taking his cue from the Mundaka, his verbal and moral association of satyam and anrtam was a common enough juxtaposition in discursive contexts by his time (we shall see that it appears, earlier, often in the Mahābhārata) and his reading of ambiguity (and, where relevant, ambivalence) in satyam and antam was commonly also that of other Hindu thinkers, irrespective of their philosophical or theological points of view.

Now, if I must express a preference, then I would say that I prefer the first, largely ontological, interpretation as a direct translation and I would admit that the second sounds somewhat forced-yet there is no doubt that vyabhicar does have the connotation of being morally deviant in some way, which gives plausibility to understanding Śankkara's explanation as signifying, perhaps obliquely, Brahman's identification with absolute Truth and Brahman's opposition to moral deviation. ${ }^{10}$ Or, to look at it somewhat differently, we can say from this understanding of Śankara's interpretation that truth is a supreme value or good in so far as it is identified with the Absolute and that its opposite, anrtam, namely, untruth or falsehood or moral instability or deviance, is to be shunned. Further, by virtue of

\footnotetext{
8 That is, change for the worse, a falling away from a stable state. His later use of vikāra indicates that he has instability in the ontological sense primarily in mind, but this does not imply that he does not also have a "defection," a falling away in a moral sense, also in mind. Hence our alternative translation.

9 Thus, the dictionary notes that the noun form vyabhicāra can also mean a crime or sin (such as a wife's infidelity).

${ }^{10}$ A number of translators of this text render satyam as "Truth" rather than as "Reality" or "the Real."
} 
this selfsame identification, the pursuit of truth leads to fullness of being for us as human beings (cf. Mundaka Upanișad 3.1.6). ${ }^{11}$ To say that this conception was commonly held by Hindu thinkers does not seem to be a contentious conclusion to draw from the sources we have considered. In other words, a lot was at stake for becoming fully and "truly" human through the pursuit of truth. For such pursuit leads us to our final destination (3.1.6). We must now inquire further into this supreme Hindu value. With the title of this article in mind, then, we can now ask "what is truth?" and consider how it relates to what is not the truth (anrtam), in the context of that central Hindu concept-dharma. Our objective is modest: to devise some understanding of what it might mean to say that Hinduism is a "dharmic" faith in relation to the concept of truth, or to put it differently, to provide a claimant for saying that Hinduism is a "dharmic" faith in terms of "truth." 12 Note, our approach is "inductive" in the sense that, for the most part, we shall be referring to an influential text with heuristic properties (including an illustrative example as shown below) ostensibly promulgated by an influential figure (the divine avatāra, Kṛ̣na), located in a source that has had considerable traction in one form or another among a broad swathe of Hindus down the ages (namely, the Mahābhārata), to offer a suggestion as to how Hinduism may be considered a dharmic faith in relation to the concept of "truth." It is open to the reader to challenge this suggestion by producing counterexamples; but then, how many counterexamples could overturn our suggestion? In other words, what is the critical mass of counterexamples that would militate against what we claim is a trend in Hindu understanding? That is the question. On the other hand, if most Hindus who read or follow our argument accept our suggestion, then the suggestion stands. Let us now continue with our discussion.

As is well known, dharma in Hinduism has multiple meanings ${ }^{13}$; but in all cases as a moral term, dharma bears semantically on "what ought to be done (kartavya)," and by implication (negatively), on "what ought to be avoided (akartavya)" or "what ought not to be done." Dharma as a moral term presides over the domains of "oughtness" and "prohibition." In this connection, I have pointed out in my book, Hindus, that

the actualization of dharma is traditionally understood to require a free and deliberate response... [by the agent, as is] indicated by its definition in an influential text, the Mìmāmsā Sūtra of Jaimini (200 B.C.E.-200 C.E.). The second verse of this text declares: "Dharma concerns some directive" (codan $\bar{a}$

\footnotetext{
11 With the exception of the "materialists" (Cārvākas) and kindred schools, all the foundational schools of Hindu thought acknowledged the scriptural authority of the Vedas (which included the Upanișads).

12 We shall not be concerned with the contrast often made between Hinduism as a dharmic faith and the so-called Abrahamic faiths. In any case, this is a simplistic contrast and overlooks important distinctions between the Abrahamic faiths themselves. On occasion, however, where it might prove useful, we shall venture a passing comment on aspects of this contrast. For an instructive treatment of differences within and between the Abrahamic faiths, with historical implications, see Abulafia 2018.

13 Matilal, in an essay entitled, "Elusiveness and Ambiguity in Dharma-Ethics" (2002b), observes, "In various contexts, the word dharma may mean: law, justice, custom, morality, ethics, religion, duty, nature, or virtue" (37), to which we may add "propriety" and "righteousness." He goes on to say, "[The] almost breathtaking complexity... of the dharma-concept seems to underline links between ways of living, ways of seeing and ways of relating to life's ultimate issues" (37).
} 
lakșano'rtho dharmah)....The point is...that according to this definition, dharmic behavior has to do with a recommended course of action. Such a directive would paradigmatically be expressed in Sanskrit in the optative mood (vidhi-lin), i.e. "One should/may (not) do so-and-so." This would make no sense unless it were assumed that the subject of the directive was free to act accordingly (Lipner 2010: 251; emphasis in original). ${ }^{14}$

This is sufficient for us now to usher in a change of scene and turn to the Mahābhārata.

It is generally agreed by scholars that the received text of this great Sanskrit epic - we shall focus on the so-called critical or Poona edition-was produced over a period of time between about the fifth century BCE and about the fifth century CE (give or take a century or two either way). ${ }^{15}$ The Mahäbhärata is well known as a repository of seminal ideas for shaping the understanding of Hindu morality, or dharma, all of which were bound up with a host of myths, tales, anecdotes, fablescall them what you will-which collectively functioned as a veritable laboratory of thought-experiments for discerning the nature of dharma, understood as that which ought to be done, or the righteous course of action, in a particular situation. ${ }^{16}$ Many of these stories exist as frame-stories or as components of frame-stories, which indicates that the text as a whole was remarkably self-aware. In other words, the text's anecdotal nature tends to generate reflective discussion. From our point of view, an integral part of this process is distinguishing between truth and what is not truth and what it means to be a truthful human being. This distinction, I shall argue, lies at the heart of what it might mean to call traditional Hinduism a dharmic faith. ${ }^{17}$ It is not by accident, I think, that the declaration, satyam eva jayate, was chosen as the motto of the new nation-state that was India, a country that was then, and still is, statistically, overwhelmingly Hindu in population. We can now move on to consider the nature of satyam - a key marker, as we have indicated, not only of the Absolute, but also of the pathway to attaining It—with the Mahäbhärata as a preeminently Hindu text as our guide.

\footnotetext{
${ }^{14}$ How the pursuit of dharma fits in with the teaching on karma and rebirth is an interesting but separate question.

${ }^{15}$ In my view, properly speaking, there can be no such thing as a "critical edition" of the Mahäbhärata, which began life as an oral text subject to the dynamics of oral transmission over time. We take recourse in this article to the so-called critical Sanskrit Poona version then only in so far as it is a conveniently available and stable reference text.

${ }^{16}$ Because of its polemical character, not least about the nature of dharma, a copy of the Mahäbhärata is not kept in traditional Hindu households, for the belief is that this would lead to dissension among the inhabitants of the house. This does not mean that certain episodes or discourses of the Mahābhārata have not acquired a generally acknowledged authority in Hindu perceptions with the passage of time, as we shall see. Dharma is also at the heart of that other great Sanskrit epic, the Rāmāyana, namely, "The coming of (the human avatāra) Rāma (into the world)," but in a subtly different way. The dharma of the Rāmāyana, especially with regard to Rāma's character, seems to imply a more settled understanding of dharma than that of the Mahäbhärata, a major objective of which appears to be to encourage inquiry into the nature of dharma.

17 "Traditional Hinduism," because, as I hope will become plain by the end of this article, this does not apply to those forms of (contemporary) Hinduism that depart from this model.
} 
We need not concern ourselves with summarizing the main plot (and labyrinthine subplots) of the narrative ${ }^{18}$ - let us begin, rather, in medias res. A great battle is being fought between two mighty armies; at the head of each is a group of warriors who are related to the opposing group as cousins. So, up to a point, we have a text here about an internecine war, with its ubiquitous moral deliberations or pronouncements all the more poignant and consequential for that. One of these groups is a family of five brothers, known as the Pạndavas, the eldest of whom is called Yudhișthira. At one point, when he sees that the battle is not going well and that his brother Arjuna, noted for his prowess, has been unable to slay Karna, a great general of the opposing side (whom Arjuna had promised Yudhișthira he would kill: mayi pratiśrutya, 8.48.3), Yudhișthira berates Arjuna in no uncertain terms and, to add insult to injury, suggests that Arjuna should have handed over his trusty bow, Gāndiva, to Krṣna, his charioteer (and also the avatāra of the Deity), who could have finished the job (8.48.13-14).

This cuts Arjuna to the quick, who in response grabs his sword to kill his brother. When Krṣna intervenes to stop him, Arjuna, still enraged, says that he has taken a "secret vow" (upāmśuvrata) to cut off the head of anyone who insults him by saying that he must make over Gāṇ̣iva to another (8.49.9). He insists that he must keep his promise (pratijñàm pālayișyami, 8.49.10), for thus he will attain freedom from debt to the truth (satye pyānrnyatām gatah, 8.49.12).

As Bimal Krishna Matilal points out, "Promise-keeping is identified with truthfulness in almost all cultures" (2002a: 9). But faced with the prospect of this awful act, Arjuna now has second thoughts. On the one hand he must keep his vow, and on the other hand he does not wish to kill his elder brother. In a bind, he looks desperately to Krṣna for help, and asks: "What do you think is appropriate at this time-you, my mentor, who know the entire past and present of this world? I'll do what you tell me to do, Sir" $(8.49 .13) .{ }^{19}$ This is the frame-episode for what follows.

Kṛnna, to whom Arjuna humbly attributes superior, indeed omniscient, knowledge, now embarks on a lecture about the nature of dharma, promise-keeping, and truth. ${ }^{20}$ At the outset, note two features of this episode, one external to the narrative, and the other internal: (a) externally, this episode has become well known in subsequent Hindu deliberations about the nature of dharma and the ethics of speaking the truth and promise-keeping (as we shall indicate in due course), especially with regard to a particular illustrative anecdote attached to it; while (b) internally, note how Arjuna refers to the need to attend to context in order to

\footnotetext{
18 A good, abridged English rendering of the story is given in Smith, The Mahābhārata (2009).

19 kim vā tvam manyase prāptam asmin kāle samutthite | tvam asya jagatas tāta vettha sarvam gatāgatam ॥ tat tathā prakariṣyāmi yathā mām vakșyate bhavān \| (Mahābhārata 8.49.13).

20 In his Krṣnnacaritra, "The Life of Krș̣na," first published in 1886, the doyen of early Bengali literature, Bankimcandra Chatterji, discusses this section of the Mahäbhärata (see the sixth chapter in Part 6, entitled "Krṣnakathita Dharmatattva," of the 1892 edition). This indicates the authoritative claims of this section. Though on occasion similar points are made, our argument follows a different course from Bankim's (see later). Further, in places there is confusion in Bankim's treatment of dharma, which is understood sometimes as that which one ought to do and sometimes in the modern sense of "religion" or "religious faith."
} 
resolve his dilemma when he asks: "What do you think is appropriate (prāptam) for me to do at this moment of time (asmin kāle samutthite)."

In his reply, Krșna implicitly endorses Arjuna's perception that a genuine dilemma obtains (otherwise he would have simply instructed Arjuna to fulfill his promise and kill Yudhișthira, however personally abhorrent this might seem); but Krṣna also acknowledges the need to take context into account, as we shall now seek to demonstrate. Early in his discourse, Krṣna makes a point that is made repeatedly in the Mahābhärata - that dharma is highly enigmatic, that it is subtle and full of intricacy, and that it is very hard to discern in this situation or that (sükșma/-tā are the terms often used to indicate this quality). ${ }^{21}$ As life's situations become more complicated, it requires a mature mind to do so, one attentive to the wisdom of the past.

Associating dharma and truth-telling, Krṣna now instructs Arjuna (we give the gist of his teaching):

No one who is aware of the distinctions (dharmavibhāga-) that make up dharma, Arjuna, would act thus (8.49.14)....He is the basest of persons who confuses what should and should not be done $(8.49 .15)$....For it is not at all easy to know what should and should not be done. It is only through proper authority (śrutena) that all can be known and that you do not know (8.49.18). ...The virtuous person does not countenance the killing of living beings (8.49.19). It is best, in my view, not to kill living beings. One can even speak a non-truth (antrtam), but one should never kill $(8.49 .20)$.... (Why are you bent on killing your elder brother then) without having resolved the subtle (sūkșmām) and enigmatic (duranvayām) path of moral matters (dharmānām (8.49.24)? I shall now reveal to you the secret of dharma... (8.49.25).

After insisting that it is very hard to discern what dharma is, that is, what should be done, in a particular situation, and that one needs proper guidance to do this, Kṛṣna exalts non-killing as the highest virtue, even over speaking the truth and not uttering what is anrtam. To make my argument clearer, I have translated anrtam here as nontruth, that is, as what is simply not the case, enforcing the distinction between the meaning of anrtam as "non-factual" or "not stating what is the case" and its meaning as "untrue" or "false," a distinction we are entitled to make according to the authoritative grammatical rule mentioned earlier. Not to state a fact does not per $s e$ imply a moral transgression, whereas a lie or falsehood seems to imply a moral transgression by definition. A myth or a fairy-tale is non-factual (anrtam in the "weak" sense), but this does not make it a lie or a falsehood (anrtam in the "strong" sense). This is well understood by mature people. So I take it that Krṣna is saying that you can prevaricate, or dissemble, or perhaps even be a bit devious by not uttering what is the case to follow the code of non-violence and save a life. This would not be a "lie" or a moral transgression. But does this mean that following the code of non-violence is an unconditional requirement? That it cannot be violated

\footnotetext{
${ }^{21}$ For another well-known episode, among many, stressing the need to discern dharma's enigmatic nature to arrive at the solution of a pressing dilemma, one can follow the narration of the dicing match in Book 2 of the Mahābhārata. I have analyzed it at some length in my Hindus (2010: Chapter 11).
} 
under any circumstances? Hardly_for this advice comes from the same Krṣna who instructed Arjuna, in the Bhagavad Gittā, to follow his caste duty and as a righteous Kṣatriya engage in the very war in which this episode occurs, even if it meant slaying his relatives and respected elders. There is such a thing as dharmic, or righteous, (mortal) combat. What has entered the discussion here is the weighing up of priorities in following a moral course of action. Speaking the truth, keeping one's word, not killing, are all dharmic, or moral, goods that need to be weighed up with respect to each other in context before one decides on a moral course of action. This will become clearer as Kṛ̣na's argument unfolds.

In order to endorse context as key to determining the relative merits of what seem to be temporarily incompatible dharmic goods, Kṛṇa illustrates his teaching by narrating two anecdotes. We shall concentrate on the second one, which, as I mentioned earlier, is well known in subsequent Hindu deliberations about the ethics of promise-keeping and truth-telling. After exalting truth, Kṛ̣na first points to the difficulty and subtlety of distinguishing between what is really the truth and what is not:

Speaking the truth is virtuous (sādhu); nothing is higher than the truth (satyam). But, in fact, it is very difficult to discern how speaking the truth should be practised (8.49.27). And it can well be that [on occasion] the truth must not be spoken, while what is not the truth (anrtam) should be uttered (8.49.28).... Sometimes what is not the truth becomes "the truth," while what is the truth becomes untruth (anrtam). Only a simple-minded person (bāla) sees truth as something to be practised thus [namely, at face-value or blindly]. But having distinguished truth [proper] from non-truth, one becomes a knower of dharma (dharmavit) (8.49.29-30). ${ }^{22}$

Here Krṣna says that there is nothing higher than the truth (na satyād vidyate param, 8.49.27); but a little earlier he has said that in his view not taking life is the best option (8.49.20). Clearly then one must adjudicate between these two goods when the occasion arises, according to the circumstances in which one finds oneself. The dramatic story of the Brāhmaṇa ascetic Kauśika that he now relates will draw us into the intricacies of this teaching not only intellectually, but also emotionally, that is, qua human beings. This is what attention to context does; it counters the making of automatic or mechanical decisions that a fortiori tend to occur in a morality that relies on the absolutizing of moral principles. Krṣna's teaching on the other hand helps make our moral decisions properly human; by drawing us in as beings of intellect and emotion (the latter has been gravely underrated in the determining of moral principles), it becomes fit for human consumption, that is, fit for purpose. After all, this is what illustrations that are relevant for our moral deliberations help to achieve. They can humanize such deliberations, without necessarily being allowed to sentimentalize them. And the Mahābhärata excels at providing such illustrations. Let me then paraphrase, and in the process duly elaborate, the illustration of Kauśika so as to give its proper moral role better effect.

\footnotetext{
22 yatrānrtam bhavet satyam satyam ca apy anțtam bhavet I (Mahābhārata 8.49.29). tādrísam paśyate bālo yasya satyam anușthitam I satyānṛte viniścitya tato bhavati dharmavit II (8.49.30).
} 
Kauśika was a Brāhmaṇa (vipra) ascetic (tapasvī) who lived at the confluence of some rivers, not far from a village. But he was not very knowledgeable in the authoritative texts (na bahuśrutah). ${ }^{23}$ Once again, mention is made here of the need to be attentive to authoritative tradition. But being attentive to (authoritative) tradition is also a characteristic of taking context into account. In discerning dharma, one cannot simply go it alone.

Now truth-telling was regarded as a special quality of Brāhmaṇas. Recall the story in the Chāndogya Upaniṣad about the youth Satyakāma (4.4.1-5). ${ }^{24}$ Satyakāma asked his mother, Jabālā, for permission to live as a student who studied the Vedic scriptures and way of life (brahmacārin). For this he needed to know his gotra, or family lineage, otherwise he would not be accepted by a recognized teacher. But his mother answered that she did not know his gotra because when she was young she moved around a lot as a serving girl and conceived him without knowing who the father was. She advised Satyakāma that he should recount the circumstances of his birth to his prospective teacher, and then simply state that his mother was called Jabālā and he was Satyakāma Jābāla. Satyakāma approaches the teacher Gautama, and when asked about his gotra repeats what his mother told him to say. And Gautama answers, "Someone who's not a Brāhmana could not speak like this....I'll take you on, my child, because you have not departed from the truth." So truth-telling, and by implication promise-keeping, were particularly appropriate acts for good Brāhmanas.

Kauśika endorses this perception by taking a vow (vrata): "I shall always tell the truth (satyam mayā sadā vācyam iti tasyābhavad vratam)." In fact, this made him well known as a speaker of the truth (satyavāititi, 8.49.42). Two matters of note here: (i) Kauśika took a vow to do what he was expected to do. Vratas could be short-term or long-term, ${ }^{25}$ but there is no indication here that this was a temporary resolution or that it was taken with some tangible end in view (both possible in the taking of vows). On the contrary, it seems that Kauśika took his vow always to tell the truth to fulfill expectations of him as a Brāhmaṇa. (ii) But can one not detect here an element of pride, perhaps even arrogance, in the words used to describe Kauśika's vow: satyam mayā sadā vācyam: (literally) "the truth must always be spoken by me." There is a cadence to these words that seems to imply the following accompanying awareness:

I am a Brāhmaṇa, an ascetic who can strengthen his resolve by his austerities [austerities were expected to achieve this], and I am famous for carrying out my vow. Nothing must be allowed to pose a threat to this state of affairs.

\footnotetext{
${ }^{23}$ kausikiko'py abhavad vipras tapasvī na bahuśrutah | nadīnām saṃame grāmād adūre sa kilāvasat ॥ (Mahābhārata 8.49.41).

24 "Satyakāma" can be translated as "lover of truth."

25 Pechilis observes that a vow (vrata) "can be long-term or short-term, constitutive or instrumental, ontological or conditional, duty-bound or voluntary, directed toward a specific deity or aimed at transforming one's life path to increase one's spiritual status-or, seemingly, almost any combination thereof" (2006: 147, cited in Pintchman 2010: 427).
} 
The fact that he was not very knowledgeable in the authoritative tradition (na bahuśrutah) that could throw light on the conditions for keeping his promise, seems to have eluded this awareness. 26

To continue the story: it so happened that one day Kausika saw a group of terrified individuals enter the forest in which he dwelt. They were fleeing from a band of bloodthirsty bandits. When their pitiless $(k r \bar{u} r \bar{a})$ pursuers arrived on the scene, they approached Kauśika and asked him if he knew where their quarry had fled. The text makes a point of stating how the bandits questioned our truth-telling Brāhmaṇa. They said: “Asked in truth's name (satyena prṣtah), speak if you know where they've gone, and tell us!" (8.49.44). The text continues: "Questioned [thus], Kauśika made a veridical statement to them (satyam vacanam tān uvāca)," and revealed where their quarry were hiding: "They've taken refuge in this wood full of dense trees and creepers" (8.49.45). Then their remorseless pursuers sought them out and killed them all.

And now for the pièce de résistance of this anecdote: Kṛ̣ṇa concludes it by saying:

As for Kauśika, by that immoral act (adharmena), by that highly illspoken word, he went to a ghastly hell. A fool, he was not knowledgeable enough of the authoritative texts and unable to distinguish the realities of dharma (8.49.46).

We may find this a surprising conclusion: apparently, our truth-telling Brāhmaṇa went to a particularly gruesome hell for keeping his vow! But Kṛ̣na continues:

Dharma has been promulgated for the development (prabhavārthāya) of beings (8.49.49). It's said the term dharma comes from dhāranam, that is, "maintaining," "preserving." So dharma sustains creatures (8.49.50).... Therefore, speaking what is not true (anrtam) for the sake of dharma, is not a falsehood (antram) (8.49.55)....Having heard this, Arjuna, tell me if [you think] Yudhișthira should be killed (8.49.56). ${ }^{27}$

In some way-which we shall investigate further-by parroting "the truth" Kauśika deviated from the proper course of dharma, so that this resulted in retribution. For his part, Arjuna decides not to honor his "secret promise" and kill his brother. He realizes that he has made an unconsidered vow that ought not to be

\footnotetext{
${ }^{26}$ In terms of Pechilis' description (see previous note), Kauśika's vrata seems to have been voluntary, and therefore, speaking technically, kämya (rather than nitya or naimittika), and undertaken to enhance his "spiritual status," but in a self-aggrandizing way; he didn't bother to study what the expert guides had to say.

27 ...prabhavārthāya bhūtānām dharmapravacanam kṛtam I (Mahābhārata 8.49.49). dhāraṇād dharmam ityāhur dharmo dhārayati prajāh | (8.49.50)...tasmād dharmārtham anrtam uktvā nānṛtavāg bhavet ॥ (8.49.55)...etacchrutvā brūhi pārtha yadi vadhyo yudhișthirah $\|$ (8.49.56). Note how anrta appears twice in the penultimate sentence we have quoted, indicating that our translation is correct, that is, the first anrta must bear a different sense (namely, "what is excusably non-factual") from the second ("falsehood"), otherwise the sentence would end up as a self-contradiction. See further.
} 
carried out to the letter. ${ }^{28}$ We can now delve deeper into Krṣna's pronouncement (made more than once in the text's narration of this incident) that on occasion, even though truth is a supreme value, parroting what is "the truth" is really not speaking the truth, but may even be regarded as untruth, and that saying what is not the truth or non-factual is tantamount to telling the truth-so long as one has the intention, and made the appropriate effort, to implement dharma. In other words, what is truth proper, and true dharma, must be discerned according to circumstance. As the Mahābhārata reiterates elsewhere:

In the inappropriate place and time, dharma is ascertained to be adharma. It is agreed that [even] appropriating [something], anrtam, and violence [can be] dharma, which is circumstantial (12.37.8). ${ }^{29}$

Our inquiry will be more effective if we now consider an opposing point of view to Krṣna's, famously maintained by one of the most influential Western moral philosophers of modern times, Immanuel Kant (1724-1804). One must not forget that Kant's thought emerged in what was still broadly a Christian conceptual environment with Christian notions of God and morality, however multifaceted, holding sway. We shall return to this consideration in due course, in connection with the term "Abrahamic."

In a short essay entitled, "On a Supposed Right to Lie from Philanthropy,"30 published in 1797 as a rejoinder to an attack on his view by a French thinker named Benjamin Constant, Kant considers a scenario remarkably similar to that about Kauśika. ${ }^{31}$ Kant first recounts his opponent's position as follows:

The moral principle "it is a duty to tell the truth" would, if taken unconditionally and singly, make any society impossible. We have proof of this in the very direct consequences drawn from this principle by a German philosopher [that is, Kant], who goes so far as to maintain that it would be a

\footnotetext{
${ }^{28}$ We need not pursue the text further. Though Arjuna acknowledges the impetuousness of his earlier intention and refrains from killing Yudhișthira, he is still keen to appear as one who has kept a promise. So, in response to Arjuna's request to salvage his "secret vow" in some way, Kṛ̦̣na provides a figleaf of a justification. He tells Arjuna to address Yudhișțira disrespectfully, for, he says, such (temporary) lowering of his elder brother's dignity would be tantamount to Arjuna's "killing" him! For our part, we must focus on the punishment meted out to Kauśika for uttering his "truthful" statement to the banditshis consignment to a ghastly hell. For this is the point of the illustration.

29 ya eva dharmah so 'dharmo 'deśe 'kāle pratișthita $\mid$ àdānam anṛtam himsā dharmo vyāvasthikah smṛtah $\|$ (Mahäbhārata 12.37.8). I am grateful to John D. Smith for locating this verse for me.

${ }^{30}$ Also translated from the German in some publications as, "On a Supposed Right to Tell Lies for Benevolent Motives."

${ }^{31}$ Had Kant heard some version of the Kauśika story, which prompted the formulation of his own example? There appears to be no evidence to suggest this. But Kant's was a period in which German savants looked to the East for cultural inspiration, which strengthens the possibility that the Kausika story was available to him in some form. Or perhaps Kant's example derived from the story of the prostitute Rahab in the Bible, who hid two Israelite spies from hostile pursuers on the roof-terrace of her home in Jericho, telling the pursuers that they had left her dwelling (cf. The Book of Joshua, Chapter 2). When the Israelite army later sacked Jericho, Rahab and her extended family who had taken refuge in her house were spared. I am grateful to Professor Robert P. Gordon for this suggestion.
} 
crime to lie to a murderer who asked us whether a friend of ours whom he is pursuing has taken refuge in our house.

...It is a duty to tell the truth. The concept of duty is inseparable from the concept of right. A duty is that on the part of one being which corresponds to the rights of another. Where there are no rights, there are no duties. To tell the truth is therefore a duty, but only to one who has a right to the truth. But no one has a right to a truth that harms others (1996: 611, citing Constant 1797: $123,124)$.

Note that Constant has understood Kant correctly in saying that Kant endorses truthtelling as an absolute principle, susceptible of no exception, by the phrase "unconditionally and singly." He also links telling the truth with rights: one should be told the truth only if one has a right to it. One has no right to the truth if, by knowing it, one seeks to harm someone else. Indeed, continues Constant, society cannot function if Kant's principle is applied from very small instances to great. We may exemplify this as follows: (a) (Knock! Knock!) "Who's there?" "Peter. Is John in?" (John is at home but doesn't like Peter. Knowing this, John's wife makes an excuse:) "Afraid not. He's out." (b) (Knock! Knock!) "Who's there?" "Peter. Is John in?" (John, who's at home, is terrified of Peter who is a gangster and means to inflict serious harm on John. Knowing this, John's wife answers:) "No, he's away."

Neither of these answers by John's wife is morally acceptable to Kant. Both of her flat denials, irrespective of whether the circumstances and consequences are minor (example [a]) or serious (example [b]), are to be reckoned as moral transgressions - as untruths or lies-and therefore as reprehensible. One could be evasive, I suppose, if that were possible, but one cannot knowingly, flatly deny what is the case, without transgressing morally. Any such conciliatory explanation for both answers on behalf of John's wife-such as "He's not at home to you" — cannot pass muster as morally permissible for Kant. Further, your being entitled to the truth in both cases (even if you're a prospective murderer) is unconditional; it is not bound up with a question of rights, or what your own intentions-good or badupon hearing the truth, happen to be. Kant responds to Constant's critique as follows:

Truthfulness in statements that one cannot avoid is a human being's duty to everyone, however great the disadvantage to him or to another that may result from it...[for I] do wrong in the most essential part of duty in general by such falsification, which can therefore be called a lie.... That is, I bring it about... that statements (declarations) in general are not believed, and so too that all rights which are based on contracts come to nothing and lose their force; and this is a wrong inflicted on humanity generally (1996: 612; emphasis in original).

There are a number of assumptions and assertions here. In the title of his reply Kant uses the word "lie." So, the conclusion is already assumed in the essay's title, for the term "lie" (and even the idiom "white lie") invariably implies a moral transgression (however minor). Kant loads the argument in favor of his conclusion from the start. Further, he asserts, contrary to Constant, that by speaking even a minor non-truth 
(for him, an untruth, for example, "Thank you for your lecture the other day, which I enjoyed"), one is breaking a basic societal contract: the expectation, or entitlement, of always receiving the truth, irrespective of the circumstances, otherwise "statements (declarations) in general...[would] not [be] believed, and so too...all rights [,] which are based on contracts [,] come to nothing and lose their force" (Kant 1996: 612).

But this is a counterintuitive, false, and puerile view. It is counterintuitive and false because social intercourse allows for and encourages non-truths in many usually trivial circumstances_- "I'm afraid he's not at home," "Yes, I liked that tie you wore the other day," "What a charming hairstyle!"- as necessary conventions for the functioning of a civilized and civil society. Every mature person knows and expects this. Only children (and perhaps those with certain psychological disorders) expect "the truth" in every social circumstance. But mature moral principles take courteous excuses and non-truths into account. This is why Kant's absolutizing of the principle of truth-telling for every circumstance is puerile and explains why Krṣna in his instruction declared that only a simple-minded person or a child (bāla) parrots the truth or practices truth-telling at its face-value (tādrśam paśyate bālo yasya satyam anușthitam, 8.49.30). Understanding what should and should not be done in a particular circumstance is the mark of a mature moral person, and this understanding is hard won-through good intentions and experience, being attentive to the deliberations of the wise (elders), and grappling with the perhaps conflicting pulls of the circumstances at hand.

No doubt, one cannot make non-factual excuses lightly. We do have the obligation to state what is the case-to "tell the truth"- - so far as this is possible. Easy convenience, and selfish advantage, cannot be legitimate criteria for the making of non-factual excuses and statements. This is why excuses must be made judiciously. However, the running of a civilized society, and the avoidance of unnecessarily offending or hurting others, must always loom large in our sights when the need for an excuse arises. This leads us to the consideration of more serious moral decisions and their consequences confronting us in difficult circumstances, and for this we must return to the Kantian version of the Kauśika story.

Here someone takes refuge in a friend's house (with the friend's knowledge) seeking to escape an individual who intends to kill him. The prospective murderer arrives at the house in search of his quarry, but the owner of the house says that he is not there. Not only is this a lie, and thus morally reprehensible, for Kant, but he goes on to make the incredible claim that:

If you have by a lie prevented someone just now bent on murder from committing the deed, then you are legally accountable for all the consequences that might arise from it.... If you had lied and said that he is not at home, and he has actually gone out (though you are not aware of it), so that the murderer encounters him while going away and perpetrates his deed on him, then you can by right be prosecuted as the author of his death.... One who tells a lie, however well disposed he may be, must be responsible for its consequences even before a civil court and must pay the penalty for them, however 
unforeseen they may have been; for truthfulness is a duty that must be regarded as the basis of all duties to be grounded on contract, the law of which is made uncertain and useless if even the least exception to it is admitted (1996: 612-13; underline emphasis added).

Once again, even when the consequences for not telling the truth are serious, we have a defensive statement-hardly an "argument"- that is counterintuitive, false, and puerile. To begin with, it is doubtful if there is any legal system that regards it as legitimate to prosecute someone as the author of a murder willingly committed by someone else that was based on what was known to be the unintended consequences of a benevolent lie meant, in the first instance, to prevent that murder, and it strikes me as irrational to postulate that this should be so. Kant's position rests, of course, on his assumption that if you allow a single exception to telling the truth, then the whole edifice of society, which he asserts depends on truthfulness as the basis of all duties grounded on contract, is undermined. But we have seen above that, to the contrary, a civilized society makes provision for what we may call excuses or nontruths for its smooth functioning, and it is expected that this is understood by all mature stakeholders of that society. A view to the contrary is simplistic, childish, and immature (bāla). ${ }^{32}$ A small crack can result in a major breach, and this, it seems to me, is what Kṛṣna has done to Kant's argument. By implying that there can be even small exceptions to the latter, Kṛ̣na has demonstrated its fatal weakness.

It is not irrelevant that when, towards the mid-nineteenth century, a debate arose between a traditional Brāhmaṇa paṇdita, Nīlakaṇtha Goreh, and a Christian evangelical-minded polemicist, John Muir, as to which faith, the Hindu or the Christian, was doctrinally superior-for Muir had initiated the debate by arguing in his Sanskrit treatise, the Mataparīkșā (The Sifting of Doctrine), that Christian doctrine was the more reasonable-Goreh, in his reply (the Śästratattvavinirnaya, or "Determining the Essence of Scripture"), could argue as follows:

A divine scripture is profound, with a meaning beyond the scope of human reasoning (nrtarkāgocarārthavat)....If your doctrine [however] were to be subjected to proper scrutiny by intelligent people, its whole meaning would seem to have been uttered by simpletons (bhāti sarvam mugdhoditārthakam). Clearly,

\footnotetext{
32 Kant goes on to reason unconvincingly to justify his stance: "It is still possible that, after you have honestly answered 'yes' to the murderer's question as to whether his enemy is at home, the latter has nevertheless gone out unnoticed, so that he would not meet the murderer and the deed would not be done. ... [If] you had told the truth to the best of your knowledge, then neighbors might have come and apprehended the murderer while he was searching the house for his enemy and the deed would have been prevented" (1996: 612-13). What is the point of these tortuous hypotheticals? They do not affect the substance of Kant's position. One can only say that they were introduced in the hope of mitigating the implausibility of his view. It is also the case that some Kantian scholars recognize the outlandish nature of this essay of Kant's and press an argument that distinguishes between the moral principle that Kant is advocating which is absolute, namely, one must never lie, and its application, which may well have exceptions. But this distinction belies Kant's own uncompromising words and argument (not to mention his tortuous hypotheticals). In any case, I am making a pedagogical contrast here between Kant's argument and Kṛ̦na's to emphasize the incompatibility of both positions.
} 
your whole teaching has a sense that is puerile (bāladhìgocarārthakam), seemingly created by men in conformity with their own intellect. ${ }^{33}$

A different argument in a different context, but the accusation is the same: Western/ Christian reasoning is simplistic, puerile (bāladhīgocara), lacking in profundity. The truth is much more complex, not susceptible to being relayed blindly via inflexible moral fiats. ${ }^{34}$ The role of reason is to try and make sense of "deep truth."

But is not truth in its religious and moral dimensions, when drawn from the socalled Abrahamic faiths of Judaism, Christianity, and Islam-“Abrahamic" at least in this: that they derive from a common spiritual ancestor, the prophet Abrahamgenerally perceived as being particularly susceptible to promulgation by imposed commandment, decree, or law, first by the Supreme Law Giver, and then by "His" authorized and authoritative representatives, where, if context is to play a part in the interpretation of such injunction, it is forever subject to the word as implacably "revealed"? I am speaking here of a matter of perception rather than of judicious discernment, in order simply to begin to explain what has become a current, popular disjunction supposedly between two different kinds of faith. But it is as well to seek to draw out this contrast here so that it may, perhaps in subsequent discussions, be subjected to more careful scrutiny.

But to continue our analysis of Krṣna's discourse with reference to what we may call the determinacy of context, there are other values/goods than telling the truth in the moral repertoire, that are not obviously to be subjected to the preeminence of truth-telling, and whose aim is also the building up and maintenance of a "good" social nexus, such as non-killing and not injuring (ahims $\bar{a})$; these also work towards the welfare and nurture of others (which one can admit Kant had in mind too). With this objective in view, such moral goods are at least as basic as truth-telling and promise-keeping. This becomes particularly obvious when the stakes are much higher, as in the case of Kauśika and that of Kant's murderous felon.

Kṛ̣na stresses this point. He has adverted to ahimsā as serving the underlying, nurturing purpose of dharma and as at least equally fundamental for the cultivation of morality and the establishment of society. Matilal pursues this point in his consideration of the Kauśika episode. Paraphrasing Kṛṣna’s teaching, he writes:

\footnotetext{
33 My translation of the Sanskrit in transliteration given in Young 1981: footnotes 102 and 104 on pages 106 and 108, respectively.

34 Goreh maintained this stance even when, after a few years of writing this treatise, to general consternation, he converted to Christianity! It was not so much a conversion to doctrine as a conversion to the person of Christ. Goreh argued later only that Christian teaching was more reasonable than Hindu teaching, not that reason could satisfactorily justify one's faith. He never accepted Muir's claim that the mark of the true religion was its clear conformability to reason. Reason can only act within a faith-stance; faith leads reason by the hand, reason grasping faith where it may. Thus, he did not repudiate or need to repudiate his earlier indictment that Christian teaching was simple-minded and rationally not up to it. His argument was now that Hindu teaching was rationally even less up to it! Yet with the passage of time, his discomfort in his new beliefs and his inability to abandon the embedded traces of his old faith plunged him into anguish. He is reported to have said, with reference to his conversion, that he often "felt like a man who has taken poison," acknowledging, "I have begun to think that it is not by going through a regular process of reason that men renounce one religion and embrace another, though such was certainly the case with me, and that is the very reason why my faith in Christianity [not Christ] is so poor" (Young 1981: 171, 172).
} 
[Krṣna] said that when Kauśika died, he did not go to heaven...for he had put his selfish religious dogma over the selfless, morally admirable action. Truthtelling may be morally admirable and hence certainly a religious virtue, but not under all conditions. One of the certain marks of morally superior (and in my scheme, "religiously" superior) action is its non-self-regarding character, as philosophers in the Kantian tradition have no doubt emphasized (Matilal 2002a: 9; emphasis added).

We may discount here Matilal's somewhat idiosyncratic use of the term "religious" (which he himself seems to admit). Like us, he wishes primarily to make a moral point. Dharma exists for the welfare of the moral agent in the wider context of the welfare of social living (and indeed, the world). And for dharma to bear fruit, it must ultimately inculcate other-regarding action over, and if necessary against, one's own personal gain or advantage. For this, discernment of the contesting pulls of dharma in a particular situation is necessary. Dharma, enigmatic and subtle as it is, is contextual in a mature moral system. Further, to discern the right course of action requires consultation with those who are knowledgeable in dharma's ways (as Arjuna shows, to his credit, by consulting Krṣṇa in his dilemma).

In the second half of the nineteenth century, the Kauśika example was taken up again by two well-known Hindu thinkers, one reaching the end of his career, the other in the earlier stages of his. The former was the doyen of Bengali novelists at the time and an influential commentator on Hindu social and moral traditions in the context of modernity, Bankimcandra Chatterji (1838-1894), who considered the episode in his tract, The Life of Krṣna. The other was the Bengali poet and essayist, Rabindranath Tagore (1861-1941), who went on to win the Nobel Prize for literature. In his discussion of the Kauśika anecdote, Bankim does not directly mention Kant or his stance in his reply to Constant. ${ }^{35}$ Bankim considers the option of Kauśika remaining silent, which he finds acceptable. But then he considers the possibility that the bandits did not allow this and forced Kauśika to speak by torture and so forth-what then? Bankim continues:

Then some might say that Kauśika should maintain his silence, even at the expense of torture and death. And we are prepared to accept this entirely. But then the question arises: is it possible for this kind of dharma to be followed generally in the world?...I do not think that the promulgation of such a dharma would bear fruit. If it did, the human race would be extremely fortunate.... So then what should one do? Knowingly tell the truth and abet the killing of human beings? Whoever thinks dharma should be thus, their view of dharma whether it be correct or not, is certainly an extremely cruel one (Chatterji 1941: 226).

\footnotetext{
35 See Note 20 for the reference. In narrating the story, there is an important difference in Bankim's reading of the text and ours. Bankim writes: "There was a Brāhmaṇa, Kauśika by name, who excelled in austerities and was well versed in the scriptures (bahuśruta)..." (Chatterji 1941: 226). The Poona critical edition of the Mahäbhärata, on which we have relied, has: "na bahuśrutah," that is, "who was not well versed in the scriptures" (8.49.41). This contrasts well with Kṛ̣na's insistence that in determining dharma one should consider the guidance of the experts, and which we have emphasized consequentially in our own analysis. Bankim's reading emasculates the reason for Kauśika's retribution.
} 
Throughout his discussion about Kṛṇa's teaching, Bankim speaks in terms of contrasting truth (satya) with falsehood or a lie (mithyā). When the welfare of others is at stake, he argues, then dharma comes into play, and when this happens, the "truth" can become a lie, and vice versa.

This is Kṛ̣na's own position: depending on the circumstance, truth (satya) becomes falsehood (mithyā) and falsehood (mithyā) becomes truth (satya), and in all those instances, [where appropriate] it is falsehood that must be implemented.... Whatever is in accordance with dharma is in fact the truth, and whatever is not so, is falsehood. Therefore, whatever benefits everyone is the truth, while what does not do so, is falsehood. In this sense, truth in common parlance (jāhā laukik satya) may be falsehood from the dharmic point of view, and what is falsehood in common parlance may, from the dharmic viewpoint, be truth. In this way, depending on circumstance, falsehood takes on the form of truth (satyasvarüp) and truth takes on the form of falsehood (mithyāsvarūp) (Chatterji 1941: 224, 225-26).

In the Bengali journal Bhāratī, Rabindranath at first disputed this view and embraced the Kantian stance. In Matilal's translation of the Bengali, he affirmed: "Falsehood can never be true under any circumstances-even if respected Bankimbabu or Śrìkṛ̣na himself says it can be" (2002a: 9), ${ }^{36}$ though, as Matilal points out, "Rabindranath changed his view later" (11)! However, Bankim's is not our interpretation of Krṣna's view. I do not think that by endorsing the speaking of anrtam as "non-truth" in certain circumstances, Kṛ̣na is advising Arjuna to commit a moral transgression, that is, to commit anrtam in its sense of "falsehood," perhaps as the lesser of two evils. I have sought to show this by appealing to the semantic ambiguity that the word anrta is capable of harboring. Krṣna is saying that, when dharma (and the wider good of others) is at stake, even by a flat denial of what one knows to be the case, morally one is telling a non-truth rather than an untruth; or, to put it differently, morally one's flat denial is equivalent to a non-truth rather than a lie (which in any case is reprehensible), so that one is not guilty of a moral transgression. Further, one could not agree with Matilal's suggestion here that, "It may be that Krṣna...gave a pragmatic solution depending upon the situational constraints" (2002a: 9). Kṛ̣na is not making a pragmatic recommendation, which again might well seek to justify a moral transgression, perhaps as the lesser of two transgressions. Kṛșna is saying that under certain conditions what would otherwise pass for the truth, ceases to be so, because other necessary conditions for its being the truth have not been met, for example the welfare or the preservation of the life of the innocent, the wellbeing of the wider community, etc. These other (relevant) conditions would all work for the maintenance and propagation of dharma which has the welfare of the whole (not necessarily only human beings in the Hindu view of things) in its purview. This is why moral deliberation implies an "organic" frame of mind, intending the welfare of the whole order of being, in the light of the guiding wisdom of the past (so far as this is known).

\footnotetext{
${ }_{36}$ Citing Rabindranath Tagore in Bhāratī, Agrahāyaṇa, BS 1291 [November-December, GC 1884], page 347.
} 
Hindu tradition has accented the need for moral deliberation in this way amid the competing pulls of dharma from early times. Dharma is inclusive and multifaceted, taking in divergent aspects of life. There are the particular dharmas of the casteorders and birth-groups (varna-dharma and jāti-dharma, respectively); the dharma of phases of life: that of the student (brahmacarya), householder (grhastha), and so on; dharma with particular relevance to the female gender (stri-dharma); dharma for the time of danger and adversity (äpad-dharma), which, once again, accentuates context by lifting the obligations of other kinds of dharma in such circumstances; sädharana-dharma, or the dharma that is applicable to all members of society (namely, practicing truth, non-injury, honesty, control of the senses, etc.), and so on. These dharmas are laid out in various kinds of dharma texts (dharmaśāstras) and have been revised, commented upon, and discussed in both Sanskrit and the vernacular down the ages. ${ }^{37}$ Theoretically, the tradition requires that when one is confronted by competing dharmic obligations one must weigh up the relevant dharmas before making a decision. Referring to an early and influential dharma code, that of Manu ( $c a$. beginning of the Common Era), which is still invoked as representative of this tradition, Matilal points out:

In the case of dispute over dharma, where it is not easy to decide which course of action should be followed....Manu suggested [in Chapter 12, verse 110] ..."An assembly of not less than ten persons, or (if ten are not available) not less than three persons, should deliberate and reach a decision on dharma, and that dharma (thus arrived at) should not be transgressed" (2002c: 59-60). ${ }^{38}$

By this weighing up of competing dharmas in a particular situation, one has the best chance of discerning what should be done (kartavya) and what shouldn't (akartavya). Thus Kṛ̣na could advise Arjuna in the Bhagavad Gìtā (which Arindam Chakrabarti describes as "the central Hindu text of practical ethics, theology and metaphysics" [2018: 19]) ${ }^{39}$ that if he acted disinterestedly, without self-centered gains in mind, that is, if he acted through niṣkāma karma, he could righteously participate in the impending great war (cf. especially Chapters 2-3). "You are entitled to [doing] the action," Krṣna tells Arjuna in the Gìtā, "never to its consequences. Let not your motive be the fruit of the action, nor should you be bent on inaction [when you ought to act]" (2.47). ${ }^{40}$ With regard to the overall intention of such action, Kṛ̣na teaches: "Just as the ignorant act attached to the action, Arjuna,

\footnotetext{
37 I have discussed these dharmas in my book, Hindus (2010), passim. Not one of these dharma codes or manuals is viewed in the tradition as having intrinsic, paramount authority. All their conclusions are up for debate. Thus, the contextual nature of dharma reigns on.

38 Matilal continues: "In verse 111, a selection procedure for these ten members was given: 'The tenmember assembly will be constituted by three scholars versed in the three Vedas...one logician (haituka...), one dialectician or arguer (tarki...), one expert in semantics and etymology (nairukta), one scholar of the dharmaśāstras, and three laymen from three different groups, one celibate student..., one house-holder... and one retired person..." (2002c: 60; emphasis in original). Clearly, such a procedure was not an everyday affair, but sanctioned by some higher authority for a particular purpose.

39 Professor Chakrabarti also discusses dharma as a concept that calls for mature discernment with respect to competing pulls.

40 karmaṇy evādhikāras te mā phaleșu kadācana | mā karmaphalahetur bhūr mā te sañgo’stv akarmaṇi $\|$ (Bhagavad Gìtā 2.47).
} 
so the wise person should act but as unattached, wanting the maintenance, the bringing-together, of the world (lokasangraha)" (3.25). ${ }^{41}$ In other words:

Since you must act, then do what the ignorant are doing, Arjuna-fight in the battle. But being ignorant they're fighting it for personal gain: wealth, revenge, territorial greed, and they will suffer the due consequences. But you must fight with no selfish motive in mind. As a righteous Kșatriya, or warrior, you must do your duty in what can be envisaged as a dharmic war selflessly, for the wellbeing of the world.

This is what dharma is for: the lokasangraha, the bringing-together, of the whole world.

Now we understand better why the everyday excuse, or the flat denial of a state of affairs, whether the matter be great or small, is justified, when it is made as selflessly as one can in the situation, for the genuine wellbeing of others, with the true purport of dharma in mind. For here anrtam qua non-truth is tantamount to telling the truth, having the same effect that in typical circumstances the truth, or satyam, has, namely, establishing true dharma. This is the mark of a mature morality and a mature social order. ${ }^{42}$

Further, it is not necessary to be perfectly disciplined as morally selfless to act in this way. That is not what Kṛ̣na advises Arjuna to do, either in the Bhagavad Gitta or in connection with the Kauśika anecdote. One must always seek to act for the good of others as one's decisive motive. If one continues in this vein, then in time one will become more self-aware, and, guided by the relevant wisdom of the experts, morally more and more other-regarding, more prone to making the right decision even at short notice. This kind of pursuit of the truth with the welfare of others as the driving motive, not only honors the truth, but also incorporates the judicious cultivation of other moral goods, such as ahims $\bar{a}$, wisdom, self-restraint, etc., into one's moral calculus; for by bringing these goods into consideration and weighing them up, one appreciates their proper place, relative to each other, in context, developing in the process a sense of responsibility for the wellbeing of the world. This approach ultimately ushers in the reign of true dharma.

It is in this way, then, that one could rightly say: satyam eva jayate: "Truth does conquer all." For, in this personal, comprehensive sense of "truth," 43 one has become true to oneself and true to the situation at hand. One has developed integrity - a sense of wholeness - not only with regard to oneself, but also with regard to the welfare of others. Looking at Kṛṣna's teaching in the round, one can say that this is

\footnotetext{
$\overline{41}$ saktāh karmany avidvāmso yathā kurvanti bhārata | kuryād vidvāṃs tathāsaktaś cikīrṣur lokasañgraham ॥ (Bhagavad Gìtā 3.25).

${ }^{42}$ I am not theorizing on the kind of ethics this may imply, that is, consequentialist, utilitarian, rights (adhikāra)-based, situational, etc. This would be the burden of a separate inquiry.

43 Again, I am not discussing the various theories of truth/error propagated by the various Hindu philosophical systems: vivekākhyāti, viparītakhyāti, yathārthakhyāti, anyathākhyāti, and so on. This would entail separate discussions.
} 
the goal of moral striving, namely, creating a sense of wholeness that incorporates the wellbeing of the world (lokasangraha). ${ }^{44}$

It is thus, I suggest, that "materially" (materialiter) - to use a logical term favored in scholastic thinking-(traditional) Hinduism is a dharmic faith, that is, a faith where dharma, or right living, is generally followed, and determined, with an eye to context; not in a way where moral dictates are imposed inflexibly or unconditionally from without, or with one's own convenience or gain in mind, but rather in the way of an integrated approach where an other-regarding moral discipline, guided by attention to the wisdom of those who are duly expert, prevails. ${ }^{45}$ But to give the pivotal Hindu term dharma only material content is not enough; we must also give it formal content, that is, a sense of conceptual direction. To this consideration, we now turn.

Dharma, in Hinduism, has never been a static concept. It has always been subject to change in its connotation, and in his book, Resistant Hinduism, Richard Fox Young has traced how this has taken place till modern times. Though he does this with a historical eye to the eventual use of dharma in what he calls "Church Sanskrit," namely, that deployment of Sanskrit used by polemical Christians (such as Muir), from about the nineteenth century, purporting to show the superiority of Christianity as a "religion" in the sense of the Greek term, threskeia, namely, "religion" as a distinctive and comprehensive way of life, he first reviews the development of this term in the Indian tradition leading up to this understanding. To this end, he alludes to the Jain use of dharma in an analogous sense.

One example in this vein from the Kṣatracūḍamaṇi, an eleventh-century text written by Vādībhasiṃha, suffices....Vādībhasiṃha there urges the man who wants supreme beatitude to take refuge in the Jain religion (dharma), which is likened to a lion that destroys elephants, a figurative expression for [the refutation of] wrong doctrines... (Young 1981: 68).

As part of the same scenario, Hindus too used dharma in this comprehensive sense. Alluding to research done by Joseph O'Connell, he points out that:

Gauḍīya Vaiṣnavas [in Bengal] sometimes used dharma as a word to express their self-awareness over against other groups, especially Muslims.... Instances of dharma compounded with hindu or hindura occur in the Caitanyacaritāmrta and the Bhaktamālā, Bengali texts belonging to the early seventeenth and late eighteenth centuries respectively.... One can say...that Gaudīya Vaiṣnavas found in dharma a useful word for distinguishing themselves from non-Hindus at the social [namely, customs-related], if not ideological, level (Young 1981: 67; emphasis in original).

\footnotetext{
44 Perhaps this also explains why "Mahātmā" Gandhi, so intent on reinterpreting ahimsā, or nonviolence, through his life, could viscerally give his (incomplete) autobiography the title, The Story of my Experiments with Truth (rather than "with Ahimsā/Nonviolence," etc.). By grappling with, seeking unwaveringly to discern - that is, by "experimenting" with - the truth in this sense, as representing his dharma, he shaped his sense of integrity, through acts of courage, circumspection, and self-restraint. This was an integrity that was intended to prioritize the wellbeing of the other in wider context (lokasaingraha). 45 Thus, Kṛṣna's teaching relevant to the Kauśika anecdote, as well as in the Bhagavad Gìtāa, are included as components of this guiding wisdom.
} 
Tāntrikas in Bengal too, he continues, used the word dharma in a sense that "designated both their praxis and conception of the divine" such that

its implication seems to be that only they possess dharma.... One finds, therefore, that the Mahānirvāṇa [-tantra, a basic text of the kauladharma: "the dharma of goddess Kālī's family"] extols itself as the dharma of dharmas: "As the footmarks of all animals disappear in the footmarks of the elephant, so do all Dharmas disappear in the Kula-Dharma"....An expression such as this

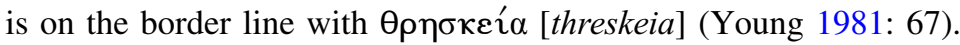

One can say that in all these cases, dharma in its generic sense connoted a distinctive, comprehensive way of life, incorporating religious customs and practices informed by a set (or sets) of beliefs that were both moral and-where this applied-theological. For Hindus, dharma in its moral connotation here continued to imply the making of judgments and decisions by way of attention to context: this did not change in so far as all the subordinate dharmas mentioned earlier continued to apply to the Hindu way of life in one way or another, even after they increasingly became subject to reform through the influence of British rule.

The resulting development in the formal understanding of dharma accelerated as the English-educated Bengali Hindu intelligentsia in the first instance (since Calcutta was the seat of British paramountcy in the nineteenth century) engaged more and more intensely with Western ideas via British rule. Yet, even then, dharma as a generic concept did not lose its contextual emphasis. What was becoming, rather, the subject of debate among the Bengali Hindu intelligentsia was the term's formal content in its connotation of an inclusive, distinctive Hindu way of life. The notes of this content varied from one thinker to another as they debated this issue, but the concept of dharma as applying to all that distinguished the Hindu way of life, remained. Ankur Barua (2017) has given us a useful insight into this debate as its trajectory unfolded. Referring to work done by A. P. Sen, Barua notes that there "were at least 13 periodicals between 1840 and 1890 with the term dharma in their titles..., where some of its significances received from the classical texts such as the Dharma-śāstras were re-envisioned by members of the Hindu intelligentsia" (2017: 2). Turning to particular thinkers, he says: "For them dharma was the basic concept with which to define the boundaries of the Hindu self even as they sought to modulate, alter, or recalibrate certain dhärmika sensibilities" (Barua 2017: 4). Thus,

the true dharma, argues [Chandranath] Basu [1844-1910]..., can be summarised in four propositions-the infinitude of God (iśvara), the Fatherhood of God, the freewill of human beings, and our love (priti) of God. This perfect dharma is, in fact, the Brahmo dharma...which is based on the Upanișads, and which is the most advanced form of the Hindu dharma (Barua 2017: 3, 8).

With regard to Bankimcandra Chatterji (whom we have encountered earlier), Barua writes:

The fullness of the Hindu dharma is the devotional love taught by Krṣna in the Bhagavad-gìtā. The scriptural foundation of the Bhagavad-gìtā provides 
Chatterjee with the tools for the form of religious humanism that he develops in the Dharmatattva, according to which the essence of the Hindu dharma is a form of culture (anusílana) which is the foundation of the four äśramas [, or stages of life], and of the diverse vows, austerities, and rituals of Hindu life (2017: 9).

We can refer to two more examples from Barua's article. For Rajnarayan Basu (1826-1899),

the Hindu dharma is universal, teaches the divine intimacy to the world, and institutes distinctions between the spiritually mature and the spiritually immature without excluding anyone, while Christianity and Islam are insular... and fail to include all individuals within their doctrinal horizons (Barua 2017: 6; emphasis added).

Whether we agree with this judgment contrasting two Abrahamic faiths with Hinduism or not, to our purpose in particular are the words in italics which clearly emphasize context for ascertaining dharma. In Barua's analysis, Basu provides a catalogue of twelve characteristics "that elevate the Hindu dharma above all the other dharmas in the world" (2017: 7, cf. 6-8). Finally,

unlike Chatterjee, [Bhudeb] Mukhopadhyay [1827-1894] frames his interrogations of European notions and his articulations of the Hindu dharma with the vocabulary not of modernised configurations of Hindu devotionalism but of Advaita Vedānta....[The] doctrine of the single self (ekajīvavāda), which implies the interrelationality of all individuals, was accepted by the extremely wise sages of the land, who believed that without the liberation (mukti) of all, no individual could be liberated....According to the true understanding of equality in Hindu dharma, all human beings are fundamentally one (mulatah eka) but are distinguished in accordance with their different karmic actions (Barua 2017: 12, 12-13, 14).

Here, in accordance with Kṛṣna's advice mentioned in our discussion earlier, Mukhopadhyay explicitly signals the importance of consulting the "extremely wise sages of the land." One could give many more examples of this modern attempt to define Hinduism in terms of the material-formal distinction. In all these cases, while dharma is materially a contextual concept, formally this contextuality must be interrogated and acted upon by means of an ethic whose defining characteristics (which vary from thinker to thinker) apply to all Hindus as a distinctive form of life.

I suggest, therefore, that to call Hinduism a dharmic faith today is to characterize Hinduism in terms of these two dimensions: the pervasive contextual-material, and the more specific defining-formal (qualifying the latter, of course, would depend on the particular sources being considered). The combination of these two aspects would set Hinduism - or perhaps more correctly, the particular Hindu way of life under review - apart in its characterization as a dharmic faith.

This is where the comprehensive notion of "truth" we have been considering comes in. Being "true" to dharma in this sense is being "true" to one's being as a person of integrity or wholeness, whose field of action has the wellbeing of the 
whole world in view, whereby the grand virtues of truth-telling, promise-keeping, non-injury, self-restraint, generosity, and so on, that is, the virtues of the sanatana ("eternal") and sādharana ("common") dharma-plus any other qualities singled out by the particular thinker under consideration - are duly combined, weighed up relative to one another, and then implemented with the demands of the situation confronting the agent in mind. Any attempt to make of Hinduism (or even a particular branch of Hinduism) a sectarian or divisive faith with a code of practice absolutized in terms of inflexible and exclusionary fiats, would run counter to the comprehensive and universalizing connotation of dharma that has been developing in "traditional Hinduism" till modern times (as reviewed by us). For according to this development, we have not been dealing with a notion of dharma intended ultimately only for a few, but with an ethic whose trajectory must eventually embrace everyone in an egalitarian way. ${ }^{46}$ If the Upanișadic dicta-both of the Mundaka and of the Chāndogya - are to be given sympathetic consideration, then it is thus, and only thus, that truth alone could indeed prevail, at least for Hinduism as a dharmic faith.

Open Access This article is distributed under the terms of the Creative Commons Attribution 4.0 International License (http://creativecommons.org/licenses/by/4.0/), which permits unrestricted use, distribution, and reproduction in any medium, provided you give appropriate credit to the original author(s) and the source, provide a link to the Creative Commons license, and indicate if changes were made.

\section{References}

Abulafia, Anna Sapir. 2018. "The Contested Seed of Abraham.” In Iris Shagrir, Benjamin Z. Kedar, and Michel Blard, eds., Communicating the Middle Ages: Studies in Honour of Sophia Menache, 239-53. New York: Routledge.

Barua, Ankur. 2017. "Vedantic Variations in the Presence of Europe: Establishing the Hindu Dharma in Late Nineteenth Century Bengal." International Journal of Dharma Studies 5, 10: 1-22.

Chakrabarti, Arindam. 2018. "Vyāsa." In Stephen Leach and James Tartaglia, eds., The Meaning of Life and the Great Philosophers, 18-26. Abingdon: Routledge.

Chatterji, Bankimcandra. 1941 [1348 BE]. Krṣnacaritra (eds. Brajendranath Bandyopadhyay and Sajanikanta Das). Calcutta: Bangīya Sāhitya Parișat.

Constant, Benjamin. 1797 [1796]. "Von den politischen Gegenwirkungen" (trans. Anonymous; original French version of the essay was entitled "Des réactions politiques"). Frankreich im Jahr 2, 5: 3-27; 6: 99-127; 7: 200-203; 8: 291-98.

Kant, Immanuel. 1996. Practical Philosophy (trans. and ed. Mary J. Gregor). Cambridge: Cambridge University Press.

Kauṇụabhațta. 1957. Vaiyākaraṇabhūṣaṇasāra (ed. S. Shastri). Anandasrama Sanskrit Series, 135. Poona: Anandasrama Press.

Lipner, Julius. 1997. "Śañkara on Satyam Jñānam Anantạ̣ Brahma.” In P. Bilimoria and J. N. Mohanty, eds., Relativism, Suffering and Beyond: Essays in Memory of Bimal K. Matilal, 301-18. New Delhi: Oxford University Press.

Lipner, Julius. 2010 [1994]. Hindus: Their Religious Beliefs and Practices. Abingdon: Routledge.

\footnotetext{
46 This is how one could explain the continuous attempts in the tradition-not only in the modern period of interaction with British rule, but from early times - to resile from the divisiveness of "caste" practices, for example (the Upanișadic teaching of Gautama to Satyakāma is an incipient case in point).
} 
Matilal, Bimal Krishna. 1968. The Navya-Nyāya Doctrine of Negation: The Semantics and Ontology of Negative Statements in Navya-Nyāya Philosophy. Harvard Oriental Studies, 46. Cambridge: Harvard University Press.

Matilal, Bimal Krishna. 2002a. "Moral Dilemmas and Religious Dogmas.” In Jonardon Ganeri, ed., The Collected Essays of Bimal Krishna Matilal: Ethics and Epics, 2: 3-13. New Delhi: Oxford University Press.

Matilal, Bimal Krishna. 2002b. "Elusiveness and Ambiguity in Dharma-Ethics." In Jonardon Ganeri, ed., The Collected Essays of Bimal Krishna Matilal: Ethics and Epics, 2: 36-48. New Delhi: Oxford University Press.

Matilal, Bimal Krishna. 2002c. "Dharma and Rationality.” In Jonardon Ganeri, ed., The Collected Essays of Bimal Krishna Matilal: Ethics and Epics, 2: 49-71. New Delhi: Oxford University Press.

Pechilis, Karen. 2006. "Singing a Vow: Devoting Oneself to Shiva through Song." In Selva J. Raj and William P. Harman, eds., Dealing With Deities: The Ritual Vow in South Asia, 147-64. Albany: SUNY Press.

Pintchman, Tracy. 2010. "Vratas.” In Knut A. Jacobsen, ed., Brill's Encyclopedia of Hinduism, 2: 427-34. Leiden: Brill.

Śankara. 1964. Ten Principal Upanishads with Śānkkarabhāṣya. Works of Śañkarācārya in Original Sanskrit, 1. New Delhi: Motilal Banarsidass.

Smith, John D., trans. 2009. The Mahābhārata: An Abridged Translation. New York: Penguin Classics. Young, Richard Fox. 1981. Resistant Hinduism: Sanskrit Sources on Anti-Christian Apologetics in Early Nineteenth-Century India. Vienna: Institut für Indologie der Universität Wien.

\section{Publisher's Note}

Springer Nature remains neutral with regard to jurisdictional claims in published maps and institutional affiliations. 